\title{
Political Turmoil Influencing Bilingual Education in the 1980s
}

\author{
Betty Alicia Cárdenas \\ Doctoral College, Texas A \& M University, Kingsville, USA
}

Email address:

bettycardenas@ymail.com

\section{To cite this article:}

Betty Alicia Cárdenas. Political Turmoil Influencing Bilingual Education in the 1980s. International Journal of Language and Linguistics. Vol. 9, No. 5, 2021, pp. 247-257. doi: 10.11648/j.ij11.20210905.12

Received: June 5, 2021; Accepted: June 23, 2021; Published: September 27, 2021

\begin{abstract}
It is not uncommon to meet young Latinx adults who were raised in Spanish-speaking households but who received all-English elementary instruction, which deprived them from further developing their Spanish language proficiency. A large part of this population is a product of our educational system from the 1990s. This archival research delves into the 1980s to uncover our bilingual education history where strong sentiments were publicized and politicized affecting the youth of that time without them even knowing it. Also included, are reflective words from a 1980s New York Times author who spoke against bilingual education then and who agreed to an interview in early 2020. From un-American claims to a need for research, the findings reveal arguments made against bilingual education in the 1980s that are strikingly similar to those that exist today. These are the views that would continue to influence, and many times threaten, bilingual education for years to come. And in one way or another, forty years later, they continue to impact our classrooms today. Bilingual educators and advocates need to be aware of bilingual education history to ensure that the current youth has a more positive experience than what was experienced by others in the past.
\end{abstract}

Keywords: Bilingual Education, History, Bilingual Education Programs, Political Views, Bilingualism

\section{Introduction}

The passage of the Bilingual Education Act (BEA) in 1968 was a monumental shift in tolerance towards bilingual education in the United States [12]. Like with many legislative decisions, there were those in favor and those opposed to the decision. It could be argued that the serious consideration for dismantling bilingual education began in the 1980s when President Ronald Reagan and other government officials attacked bilingual education through deregulation of previously implemented policies with the ultimate goal of dismantlement $[17,25]$. In 1983, the U.S. English organization claimed that to declare English as the official language was to expand English-learning opportunities for immigrants, but later openly questioned the effectiveness of bilingual education and instead hindered language minorities' access to society [19].

Because national views and legislation can directly impact educational policy [62], this archival research, focuses on the perspectives spread in favor and against bilingual education in the 1980s. As prospective bilingual education teachers prepare, emergent bilingual teachers gain their footing in their bilingual classrooms, established bilingual teachers gain a voice for advocacy, and administrators support and empower through bilingual education programs, it is important to have a thorough understanding of the strong and winding roots that anchored bilingual education and allowed it to grow into what it is today. Knowing the initial views in favor and against bilingual education can help educators make their own decisions of the progress or lack thereof that bilingual education has made in our society. Additionally, this knowledge could better equip educators to have vigorous and zealous discussions as they continue to advocate and find the support needed for the academic, linguistic, and social success of their students, which can be gained through effective bilingual education programs.

\subsection{Research Questions}

1. What were the arguments made against bilingual education programs?

2. What were the arguments made in favor of bilingual education programs? 


\section{What solutions were offered? If any?}

\subsection{Theoretical Framework}

History can be described as knowledge that is acquired and meaningfully interpreted in and through narratives of the past [24]. To analyze the archives gathered, a historical study research framework was employed. The triad of history from Nordgren [48] is borrowed to communicate the information. Additionally, to organize and present the findings, the three features of history inquisition proposed by Retz [53] is used. In this way, both frameworks are utilized and combined for a thorough critical analysis.

The triad of history incorporates: (1) historical culture, which can include past rituals, archives, narratives, and artifacts; (2) the use of history, where these historical culture aspects are utilized to communicate meaning and actionoriented messages; and (3) historical consciousness, the process through which we understand and use history [48]. The historical culture of this study includes 15 newspaper article archives from the South Texas Archives located at the Texas A\&M University in Kingsville, 20 articles combined from The New York Times online database and The Washington post online database. The archives collected highlighted the political conversations and viewpoints of bilingual education in the 1980s. The findings and discussion use this history to communicate meaning and eventually propose action-oriented messages. For historical consciousness, the process through which the study's historical culture is understood, it is helpful to turn to Retz's [53] history inquisition features through which he declares that historical researchers must be able to study the past as something that presents itself to be understood as a world of meaning outside of the inquirers themselves.

The three features of historical inquisition entail: (1) colligation, where events are organized into a whole; (2) historical distance, when the inquirer illuminates a past context separate from the present; and (3) reconstruction, where the past is reconstructed to provide content representation, and meaning that is constructed from a point of view that is not the historian's own [53]. Because it is important to provide the facts from which the decoder can make their own interpretations, the findings are presented through the organization of themes found in the archives, leaving out the researcher's own interpretations and viewpoints. The hope is that both opponents and proponents can read the facts without outside interpretation so that they are able to use their own present to reconstruct their own meaning from the archival findings.

In the discussion, the researcher uses the history to interpret and offer action-oriented messages. The interpretation of the findings are presented through Nordgren's [48] framework of four analytical levels: (1) identify and contextualize the communicative setting; (2) interpret the performative action; (3) interpret the basic reasons as expressions of historical consciousness and historical culture; and (4) interpret the interaction between the actors, which in reality happens throughout the aforementioned levels. All four levels will be reserved for the discussion section after the findings have been presented through historical distance.

The archive search in The New York Times online database led the researcher to the article English, Not Spanish by Dr. Mujica [42] who agreed to a virtual interview to answer questions about the past and possible new perspectives. Because the interview includes someone, other than the author, from the present speaking about the past, the interview findings are presented in a separate subsection and then incorporated in the discussion themes. Although some of the interview questions did not specifically address the research questions, an interviewee who had a voice in the past and is a voice now can bring perspective to the arguments in favor and against bilingual education. In this way, the interview was vital for a more in-depth description of the past and a glimpse of what has, and has not, changed in the present.

\section{Findings}

Because bilingual education in the $21^{\text {st }}$ century continues to be a heavily debated field with reasoning in favor and against, the purpose was to uncover arguments from the past in hopes that they can inform the present. To apply historical distance and allow for the readers' reconstruction, findings are organized based on the research questions: (1) What were the arguments made against bilingual education programs?; (2)What were the arguments made in favor of bilingual education programs?; and (3) What solutions were offered?. For each question, the themes that emerged are compiled and presented while leaving the author's critical analysis until the discussion section. In the arguments made against bilingual education there were four themes that surfaced: a failed goal perception, language diversity and funding, teacher shortage, and no proven method. The four themes for arguments made in favor of bilingual education were: minimizing the language barrier, success and cognitive benefits, pedagogically uninformed, and collaborative effort. There were some solutions found through the archives, from which the following themes were noticeable: resources of time, community and funding, assets-based, and autonomy.

\subsection{Arguments Made Against Bilingual Education}

\subsubsection{A Failed Goal Perception}

Entering a new decade, at the beginning of his presidency in 1981, President Reagan shared his sentiments on bilingual education, "It is absolutely wrong, and against American concept to have a bilingual education program that is now openly, admittedly dedicated to preserving their native language and never getting them adequate training in English so they can go out into the job market and participate" [4]. Very often bilingual programs say they will help students gain English proficiency, but some teachers in the programs are not English proficient themselves and they end up keeping students in non-English classes longer than necessary because it is easier [33, 36, 59]. We have allowed the ability to live and die in America without ever being educated nor learning a 
word of English, yet we don't realize it because it happens in a world apart from mainstream America, the barrios [39]. The transitional bilingual education programs did not lead to a transition into English competency of non-English speaking students [13, 57], instead they promoted cultural isolation [35]. Secretary of Education William Bennett contended that bilingual education was no longer seen as a practice to ensure the learning of English, rather it had become an emblem of cultural pride and appreciation for cultural heritage, a means of producing a positive self-image in the student [35]. We are still a melting pot, but the pot has been filled with material resistant to melt, and the fires under the pot burn very low [39].

\subsubsection{Language Diversity and Funding}

The bilingual education problem is complicated further by the fact that, in order to be in compliance with the bilingual education requirement, about fifty languages would have to be covered, an absurd demand in cities where students may come from all over the world [31, 45]. Nevertheless, Michael Resnick of the National School Boards Association said the major problem was money because there was a low 1: 15 student ratio receiving assistance due to a lack of funding [58]. Throwing federal funds at the problem is a losing battle because students are dispersed across the nation learning in different communities with different needs [39]. Secretary Bennett mentioned that after 17 years and $\$ 1.7$ billion in federal involvement and funding, there was still no evidence that the language minority students had benefited $[22,44,50$, 61]. Hensel [32] captured Secretary Bennett's declaration that the federal government would not continue to throw good money after bad.

\subsubsection{Teacher Shortage}

Others claimed that the problem was that the federal government was mandating bilingual education while not providing funds specifically for recruiting and training teachers [32]. Bilingual education is failing, primarily because we lack enough Spanish-speaking teachers [39]. Dallas, TX only had 300 of the 600 teachers needed to serve language minority students through bilingual education programs [38]. Some educators expressed not wanting to be bilingual teachers because they felt bilingual programs were ill-planned, poorly implemented by administration, lacked materials, and it required more curriculum planning, not to mention the multiple emotional demands of teaching in an emotionally charged and complex setting of minority classrooms [38].

\subsubsection{No Proven Method}

Evidence to support the bilingual education theory is weak and it is probably because bilingual education is slowing down the progress of Hispanic children [59]. There is a lack of consensus on which bilingual education approach is the most effective [31, 38]. The traditional American method is to put the non-English speaking students in all-English-speaking classes, which used to work wonders even if it sounds heartless [35]. Immigrants from the past understood the need to learn English and did so in a hurry for survival and advancement [39]. Tom Nix, board president for the Corpus Christi Independent School district, expressed he always felt like intensive English language training was the best way to go because, under the bilingual education system, students did not seem to be transitioning into English quick enough [46]. Bennett alleged that, "as fellow citizens we need a common language; in the USA, that language is English" [35].

\subsection{Arguments Made in Favor of Bilingual Education}

\subsubsection{Minimizing the Language Barrier}

In 1981, State Senator Carlos Truan stressed that a child not understanding the teacher's language was just as harming as not being able to see the chalkboard [10]. Bilingual education is essential to children who initially speak a language other than English; they will learn best when they are allowed to learn English while also progressing academically in their dominant language [14]. Reagan clarified his stance on bilingual education by stating, "where there are predominantly students speaking a foreign language at home, coming to school and being taught English, and they fall behind or are unable to keep up in some subjects because of the lack of knowledge of the language, I think it is proper that we have teachers equipped who can get at them in their own language and understand why it is they don't get the answer to the problem and help them in that way" [4]. We know that the best way is a gradual introduction of English [33]. Bonilla, president of the League of United Latin American Citizens, mentioned that bilingual education programs were designed, not only, to ease and expedite the use of English, but also as a method to compensate for the decades when Hispanic history and culture were overlooked in public education $[3,59]$.

\subsubsection{Success and Cognitive Benefits}

Seeing positive results, Miami school leaders reflect on 25 years of their bilingual education programs implementation and contribute to the discourse with their result being a highly advanced and diversified system that can be adapted to fit the various language proficiency levels and needs of the students they serve [60]. Kenji Hakuta, a Yale University psycholinguist presented research study findings that demonstrated the mental flexibility benefits and superior cognitive abilities in bilinguals as opposed to monolinguals [37]. Unless students can develop cognitive abilities in a language they know best, they will encounter challenges in learning a second language while also attempting to develop critical skills in the subject areas [13]. In a letter written by Lulu Flores [21] to TX House Representative Albert Luna, she informs him of Hakuta's study to also cite his caution against forcing bilingual children into English-speaking classes, as it can be counterproductive emotionally and intellectually. Psychologists emphasized that a bilingual program that disregards the child's home language makes that child suffer [47].

\subsubsection{Pedagogically Uninformed}

Assistant superintendent from Newark, NJ claimed the 
motives of Secretary of Education William Bennett to remove bilingual education federal mandates were political and not pedagogical [50] they simply did not understand what bilingual education was nor had they witnessed the instruction [58]. San Antonio school district superintendent Victor Rodríguez and Mario Benitez, chairman of the Department of Curriculum and Instruction at the University of Texas spoke in favor of the pedagogical practices implemented through bilingual education programs, which included regular coursework taught primarily in the home language with classes that taught English as a second language $[56,58]$. In contrast, attempting to implement the immersion model, where there is a high number of language minority students, would not work because there would not be anything to really be immersed to [39].

\subsubsection{Collaborative Effort}

Texas Governor Mark White felt that if bilingual education was going to work, strong state commitment for language instruction was crucial, which in Texas he believed that to be the case [5]. Similarly, Dr. Ana M. Guzmán, president of Texas Association for Bilingual Education argued that bilingual education programs work if administrators, school boards, and communities support it [46]. Lucy Contreras, bilingual education director for the West Oso school district claimed that if districts failed to show positive results, it was because they had bilingual education in name only, without effective implementation and support [46]. Tony Bonilla, chairman of the National Hispanic Leadership Conference declared that continued support for bilingual instruction was crucially essential at a time when the Hispanic dropout rate was at forty percent [13]. A Houston board member, Johnny Mata, said Hispanics were well aware of the importance and need to communicate in English and bilingual programs had played a vital role in meeting that goal; without it, Hispanic's learning opportunities would be even more limited [13].

\subsection{Solutions Offered by Stakeholders}

\subsubsection{Resources of Time, Community, and Funding}

Dr. Maria Luisa Garza, head of the Gulf Coast council of La Raza in Corpus Christi believed it was unreasonable for policymakers to purport the failure of bilingual education without giving districts more time and opportunity to implement the programs [56]. To demand better programs, Spanish-speaking parents and Hispanic political organizations worked together [38].

One funding perspective was set by State Senator Carlos Truan who proposed a raise in the per student state allotment from $\$ 45$ to $\$ 150$, which he supported by pointing out that it was still significantly less in comparison to the \$750-plus per student allotment allocated for blind and handicapped students [10]. To address the need for qualified teachers, he suggested that $\$ 5$ million of the $\$ 22$ million bilingual education allotment be dedicated to the recruitment of teachers [10]. A US Judge, Barefoot Sanders, felt school districts had to respond, not only to the teacher shortage, but the need for more resources and attention to the Hispanic student's needs [38]. On the other hand, Shannon [59] recommended that federal money distributed through the BEA, now be used exclusively for teaching English speaking, reading, and writing to all the non-English-speaking children.

\subsubsection{Assets-based}

After Kenji Hakuta's study finding the superior cognitive benefits of bilingualism, psychologists hoped that the findings would offer a solution by countering the increasing deficit in American's ability to speak a foreign language [47]. Rather than eliminating or keeping bilingual education programs, Connecticut expressed the possibility of instead expanding them to include English-speaking students whose parents were interested in them learning a foreign language [55].

\subsubsection{Autonomy}

Secretary Bennett, under President Reagan, sought to pass a bill that would allow Congress to authorize greater flexibility for local school districts to teach non-Englishspeakers in ways that work $[35,58]$. Reagan administration officials clarified that their goal was not to return to the infamous days of sink-or-swim nor to eradicate bilingual programs $[22,65]$. Their goal was to allow America's schools to explore more promising alternatives instead of stubbornly holding onto bilingual education [22, 31, 61, 65].

Since it is not clear that bilingual education is as ineffective as Bennett maintains, nor as successful as successful as defenders allege, we must continue to experiment a variety of approaches and not be restricted to any single program of bilingual education [61]. Within a more restricted view, Morris [39] proposed two priorities: (1) to teach English, even at the price of the loss of a year or so, and (2) to implant an idea in the barrios, the idea that English is here to stay, having a constitutional amendment making English the official language could help. "In reality, the answer is simple...at any price, the children must learn English" [39].

\subsection{From the 1980s to Now, 2020: An Interview}

\subsubsection{Background}

Dr. Barbara Mujica, a recently retired Georgetown University professor, first described how her journey toward becoming multilingual began at a young age. She grew up in an English only speaking home in California, but always frequented with Spanish peers. She was a French major, but she also took Spanish classes where she had the opportunity to refine her Spanish language proficiency. In fact, her first job was as a Spanish teacher, because at the time French would not get you a job. She eventually pursued her $\mathrm{PhD}$ in Spanish literature, wrote a plethora of novels, articles, textbooks, and anthologies, to name a few. Personally, she married a Latin American with whom she speaks Spanish at home.

After answering the initial background question, the next few questions focused on (1) her essay Bilingualism's Goal [41], which was named one of best 50 op-eds of the decade by The New York Times, and (2) English, Not Spanish [42], which was a succinct version of Bilingualism's Goal [41]. 
Because one of her statements in these articles was "Mine is a Spanish-speaking household. We use Spanish exclusively. Instilling in my children a sense of ethnic identity is my role; it is not the role of the school system", one of the questions inquired about her children's current bilingual fluency, appreciation, and any challenges she may have encountered by using Spanish exclusively at home. Dr. Mujica expressed that all three of her children speak and understand Spanish at different levels, and they appreciate the need to learn languages. Growing up, her kids stopped wanting to speak in Spanish when they entered school because English was the reinforced language. Taking a deep breath, she reflected on how hard it was to maintain Spanish at home which eventually led to tension and led her to stop insisting. She did add that she didn't think it was bad that schools reinforce English, but did find that for kids like hers, it was unfortunate not to keep it up. By the time her third child was born, the older two were speaking English. "He throws in my face and never lets me forget that I didn't force him to learn Spanish". A positive experience for him was when he traveled to South America during graduate school and was able to speak Spanish to the locals. He was even elected group leader because of his English and Spanish proficiency that proved beneficial in the various countries they visited. "I can't believe I speak Spanish," he called to say one day.

\subsubsection{Arguments on Bilingual Education}

When asked about the arguments she remembered in favor and against bilingual education during the 1980s, Dr. Mujica reflected on unpleasant comments and twisted words after her articles were published. There were those who thought the people wanting to make sure kids learned English were racist. To make her statements clear, Dr. Mujica explained that she believes in the benefit of foreign languages in school and she tells her students, who are not native Spanish speakers, that when you learn a new language, you expand your horizons. She does feel that people who come to this country make a choice and they need to accept the responsibility to learn English. She emphasized that she was not suggesting that people should refrain from speaking their native language; they can speak whatever they want at home. Dr. Mujica mentioned that we know the best way is not to expect a kid to lean English by osmosis, and "we know the best way is a gradual introduction of English". She doesn't think bilingual education classes in which children are taught Spanish for years and years are effective. Rather programs can be very effective when students are eased into English and then be mainstreamed. Opposed to bilingual education were those who didn't want any special treatment and preferred the sink-orswim model. She pointed out that although she doesn't believe this is a racist country, there are people who just have a negative attitude and don't care. And those people also don't agree with her view of kids being able to learn as long as we find the right program for them; "I want them to succeed".

\subsubsection{Living in a Foreign Language Environment}

In one of her articles, Dr. Mujica describes an immigrant author's experience as "having to exist solely in English made her feel mutilated". She was asked to consider how that statement could relate to US-born English Learners who only speak Spanish and enter early childhood settings where an English-only curriculum is established. Dr. Mujica compared it to her traveling experiences in Latin, African, and European countries where she didn't always know the language. "She understands the experience," she said. Nevertheless, she did point out that when you go live in a country, not visit, we cannot expect the country to adjust to our traditions. Additionally, her grandson currently lives in Germany and functions in German. She reiterated understanding the experience because when she Facetimes with him she only speaks to him in English and he's told her that it's a treat for him to get away from speaking German. "You know, speak his native language. There's something very lovely about that," she said.

\subsubsection{Culture in Schools}

In Bilingualism's Goal [41], Dr. Mujica stated, "I differ with educators who advocate for bilingual education programs whose goal is to preserve the Spanish language and culture among children of Hispanic families". She reaffirmed her statement by saying that it is great to expose students to multicultural rich experiences of a wide range of cultures, but it is not the school's role to teach them to be good Mexican or Guatemalan citizens. They should not be made to feel ashamed of where they're from; it's great for them to be proud of their heritage. However, she would like them to be proud of being Americans too. Additionally, they need to realize that when bad things happen, we need to find a solution, not reject the whole culture. She concluded by affirming the role of the school was to give these kids a broad knowledge, including a broad knowledge of American culture and history.

\subsubsection{Hispanic Dropout Rate}

The Hispanic dropout rate in the late $1980 \mathrm{~s}$, as referenced by Dr. Mujica, was at a high $40 \%$. She was asked to explain her reasoning as to why these statistics might have changed. She did mention looking into the current statistics that showed an all-time low Hispanic dropout rate of $10 \%$. In her opinion, this was due to four possible reasons. First, there are more Hispanic children fluent in English because many more are born here. "At the time of the previous study, many of the kids spoke English imperfectly and they were from poor families who did not stress education; putting food on the table was priority." Another reason mentioned was that colleges have made a determined effort to recruit Hispanic high school graduates. Furthermore, immigration rates are down. Before with a constant flow of immigrants, children were constantly speaking Spanish, making it harder to become fluent in English. Now people who are here have a better chance to assimilate or at least integrate into the English-speaking community. Lastly, Dr. Mujica did point out the fact that she has known of the common University practice of grade inflation for all students. So, when we look at the better grades for everyone, not just Hispanics, "I don't know if it's really a measure of what they've learned," she concluded. 


\section{Discussion}

To first contextualize the communicative setting, connections were made across the findings in the different sections: arguments against, arguments in favor, proposed solutions, and an interview [43]. The findings yielded four themes: un-American claim, English as the focus, bilingualism: a valuable skill, and need for well implemented programs. The critical analysis to communicate meaning and action-oriented messages is organized within these themes. Additionally, included are the author's interpretations of the statements and reasons behind them as expressions of historical consciousness and historical culture.

\subsection{Un-American Claims}

A number of statements were made characterizing bilingual education as a non-American approach. Some even pressed for the "traditional American" method even if it was heartless because it used to "work wonders" [35]. Considering the frequently mentioned wasted money, high Hispanic dropout rate of $40 \%$, and Spanish-speaking students being said to perform lower than other student populations $[22,44,50,61]$ it does not seem that opponents truly believed pre-bilingual approaches were working wonders. Unless of course working wonders was code for assimilation. For matters of immigration into the United States, an influential yet controversial book at the time was Assimilation in American Life: The role of race, religion and national origins by Milton Gordon [30]. This book described assimilation in relation to the melting pot ideology where immigrants were expected to conform to the white AngloSaxon Protestant core group [52]. When individuals are expected to conform to the majority culture, they are systematically limited from their own values, beliefs, and traditions. With this understanding, it is possible that those opposed to bilingual education were simply regurgitating the assimilationist expectation popular at the time. When individuals from different cultures continuously come into contact, change is inevitable. Similar, yet different from an assimilationist, monoglossic perspective, is acculturation. In the acculturation model both cultures evolve as an intercultural, two-way process in which individuals of each culture fluidly borrow and learn from each other [2, 52]. Acculturation can take the form of, more specifically, cultural pluralism which is born from the reality of everyday life that does not measure up to the 'melting pot' ideology [35]. The civil rights movement from the 1960s also prompted the "new ethnicity movement" which involved cultural identity notions toward greater pluralism in the quilted United States [35]. Therefore, it is highly plausible that bilingual education was not being seen by everyone for its sole needs and benefits. Instead, in some cases it was being utilized as a tool to push and resist a political agenda.

Having the advantage of looking back from where the 2020 United States culture stands, there is no doubt that our country, now more than ever, is one of diversity with an acculturated society. Those who do not resist, thoroughly enjoy holidays, customs, food, style, and music, to name a few, from various other cultures possibly prominent in their communities. Cultural identity can be understood as a shared system of communicative practices that is enduring of time and cannot be understood as a single variable [35]. To live in the United States and be proud to live here, to be patriotic, does not require the emotional detachment from one's roots, including their ancestry; it does not require assimilation. On the contrary, to be proud to be an American is to embrace diversity; being American is to encourage each other; being American is to accept oneself as part of a larger, complex, endlessly evolving system. All ethnicities coming together without losing perspective of the many components that contributed to making each and every one of us unique, THAT is being proud to be an American.

Therefore, preserving and addressing cultural identity and pride does have a place in bilingual education because it provides validation to our students. It is not about teaching them the history of other countries, nor showing them how to be proud citizens of other countries. It is about them embracing their language, their heritage, and seeing how it fits into the community they live in, which will then allow them to have a greater appreciation for themselves and their society. Producing a positive self-image in our students is about empowering them for who they are, highlighting their strengths and teaching them to recognize their assets...showing them they belong. It behooves educators to understand that politics and economics drive schooling in a way that oppresses individuals who do not have access to the tools of agency, mainly language and historicity [51]. Educators need to reconnect with history so as to learn from the thousands of Chicano high-school students in the 1960s who demanded quality education, cultural dignity, and an end to cultural violence [36].

\subsection{English as the Focus}

"In reality, the answer is simple... at any price, the children must learn English" [39]. "The English-only" movement was an effort to change national immigration law and bilingual services in the 1980s [33]. Throughout the decades, there have been studies that correlate the opposition to bilingual education with both prejudice and perception of threat toward immigrant groups, particularly Latinos, among AngloAmericans [6, 34]. Some people feel that English represents a national identity, and therefore English-only initiatives are pushed into the educational field through which linguistic and ethnic groups are targeted [9]. This is as true now as it was in the 1980s.

When influential members of society make statements that emphasize the sole use of English in the United States, the sentiment continues to seep its way into the classrooms. The dominant ideology sustains discrimination by ignoring the linguistic and cultural diversity of the students in schools today [9]. And although immigration politics persistently influence bilingual education, the separation between the two must be made and instead address them in isolation. In fact, against popular belief, a study conducted by Sanchez [57] 
showed that out of all English Language Learners, as is the national term, only $15 \%$ are foreign born. Therefore, the majority of emergent bilinguals developing English as a second language do not have any responsibility to accept after coming into this country, they ARE this country. Even the $15 \%$ who did immigrate did not make that personal choice, it was made for them. These are children who rely on their parents for their home upbringing and rely on educators for an equitable education. They rely on educators to unite and continue the uphill climb so that they will not be forced to live in such contradiction [26].

\subsection{Bilingualism: A Valuable Skill}

Although not as prominent as the other arguments or solutions, after Hakuta's study in the 1980s, some statements were made toward the cognitive benefits of bilingualism and the possibility of offering bilingual education to monolingual English students. Because the research on bilingualism as it relates to cognition was nascent in the 1980s, it is understandable that it was not mentioned as much as other rationales. Nevertheless, nearly forty years later, the studies on cognitive and executive functioning benefits of bilingualism in comparison to monolingualism are abundant.

Interestingly enough, most recently, Kenji Hakuta himself assisted in a study that demonstrated the higher performance of more balanced bilinguals in non-verbal tasks of cognitive function $[8,52]$. Another study by Morales, Gómez-Ariza, \& Bajo [40] used experimental conditions where higher requirement of proactive-reactive control adjustment was required and found that bilinguals outperformed monolinguals. Other cognitive benefits of bilingualism have also been linked to cognitive flexibility and cognitive control processes in social categorization tasks [37]. These results endorse an assets-based view of bilingualism, where more balanced proficiency in two languages is associated with enhanced cognitive function [63]. As if the cognitive benefits weren't reasons enough to advocate for bilingual education, there are also the social-cultural and economic benefits to bilingualism. A study by Agirdag [1] included adults who had been in schools in the 1980s to compare the effect that bilingualism had in their earnings. Those who were more balanced bilinguals, developing their native language further, earned about $\$ 2,700$ more annually.

The increased findings on cognitive and economic benefits have led to dual-language classrooms where monolingualEnglish students are being enrolled to also reap the benefits of bilingualism. Sadly, in some dual language programs the non-English speakers are invited into the programs under the pretense that they will benefit; meanwhile serving the needs of the dominant group and their gain of social-economic power [9]. To language minority students, bilingual education is a need while for monolingual-English students, it is what the parent wants. Yet another unintended result of advocacy for bilingualism and social justice, and yet another reaction with the same hegemony ideology. That is not to say that monolingual-English students should not be allowed in the programs, but it does mean that assurance of equitable participation and resources should be addressed and evaluated consistently.

In the United States and worldwide, it is not uncommon for multilingualism to be the reason for attaining a job, earning more money, and moving up in the workforce. Learning a new language undeniably expands our horizons. "Though it seems contradictory and hypocritical to accept and praise foreign language bilingualism, while at the same time removing potential for bilingualism from students who come from nonEnglish-speaking homes" [9]. Comparable to the tie of immigration and bilingual education, foreign language teaching is not the same as bilingual education and the two should not be equated. Bilingual education is native language teaching, native to the child, native to their family, native to this land, along with also learning English. Language minority students who enter into early childhood bilingual courses have an advantage because what others will be learning as a foreign language later, they already own. That is of course until an allEnglish curriculum strips it away.

Parents cannot and should not be expected to maintain the home language when they are competing with the monoglossic views and systematic oppression that some schools engrain into our students. Students should not have to wait until they get home to understand what is being said. This only widens the learning gap and can contribute to the low passing scores frequently reported compared to other minority groups. Instead, it is the schools' role to provide students access to the content, doing so in their native language is the best way to do that. Providing instruction in a language they understand not only gives them access to all the content areas, but self-validation, cognitive benefits, and a prosperous socioeconomic future. It is with this multitude of knowledge that the new door of opportunity in bilingual education must be reconstructed - above all, with an absence of malice or exclusivity [49].

\subsection{Need for Well Implemented Programs}

While some of the themes mentioned above were more prevalent in some sections than others, the need for well implemented programs was a message that echoed throughout all three sections. Whether they were opponents or proponents, there seemed to be an agreement in the need for well implemented programs. In the 1980s, bilingual education was a nascent field. It had been less than twenty years since funding had been provided for experimental bilingual education programs through the BEA of 1968. Many programs were still in the research phases with experimental programs as educators also attempted to gain new knowledge of second language acquisition, pedagogical practices, and routines that would prove to be most effective. Educators were learning through implementation, and also battling with years of oppression and continued opposition. Opponents were anxious for results and a return to an English-only curriculum, or at least the option of it. While proponents knew that an English-only curriculum, nor the option for it, was the best answer, they were limited on the research to prove that bilingual education was the best 
alternative. With the very first doctoral bilingual education program in the nation established in 1975 at Kingsville, TX, the amount of research in the bilingual education field was promised to change.

In stark comparison to the 1980s, in the year 2020 there are a multitude of studies in the area of bilingual education programs and their benefits. Study after study has demonstrated that students in dual language programs as opposed to programs where the native language is nonexistent, or used to a minimum, score higher academically over time [28, 29, 64]. In the most comprehensive of studies with longitudinal data of over 30 years, Thomas and Collier [15] have shown that "English-only and transitional bilingual programs of short duration only close about half of the achievement gap between English learners and native English speakers, while high quality long-term bilingual programs close all of the gap after 5-6 years of schooling through two languages." Therefore, the need for proof of the 1980 s is not a need anymore. Unfortunately, what has remained the same, as Escamilla [20] describes, is the scarcity of bilingual education and/or culturally responsive education programs which results in inequity for an overwhelming majority of bilingual students in our nation. Consequently, a half-century later, even with hundreds of studies under our belt, students entering schools with a language other than English persistently suffer under these pervasive inequities in public education and it requires immediate reparation [17].

Education language policies, instead of based on recommendations from educational research, continue to reflect social and political perspectives related to race, class, and immigration status [18]. Because bilingual education is likely to continue being tied to immigration and other political agendas, educators must first and foremost have the ability to recognize the difference between opinion-based and research-based solutions. Educators are the experts, not the politicians not the opinion writers, not professors in other fields, but us, we, nosotros. Educators cannot prevent anyone from having nor voicing their opinion. Although we most certainly can, and should be able to, value our knowledge as bilingual educators and experts in the field above those who do not hold a degree in bilingual education nor have ever taught the discipline. Regardless of their influence and expertise in other fields, if decisions are being made for bilingual education, then those decisions should be made by professionals who know the arena inside and out.

Bilingual education authorities and advocates have the charge of spreading awareness to all stakeholders in the community; we are the voice. In a study conducted by Bernstein, Kilinc, Deeg, Marley, Farrand \& Kelley [7] bilingual teachers teaching in dual language programs expressed concern of the tension felt between implementing other emphasized district priorities and dual language instruction. Other teachers reported the need for more resources and training. Even when educators welcome the pluralistic ideology of dual language bilingual education programs, without proper administrative support, materials, training and professional development, teachers can be limited or constrained in implementing the program [23]. Through collaboration, school communities can outline research-based instructional practices that present curriculum in a linguistically, culturally and academically responsive way [9]. As were the calls for community and collaboration back then, the same is true today. If schools and their bilingual students are to reap the multitude of benefits bilingualism has to offer, all stakeholders including, but not limited to, board members, superintendents, curriculum and instruction personnel, administrators, parents, and teachers, must support and work toward the same goals: linguistically, culturally and academically responsive instruction.

Addressing the need for teacher shortage, the lack of supply, for the high demand of bilingual students is also critical for the implementation of effective dual language programs. At the moment, the solution can be revising state certification requirements and offering Spanish language proficiency professional development. However, the longerlasting solution is once again effective bilingual education programs. Many of the teachers that have limited Spanish language proficiency, particularly in states of high Hispanic populations, are the very same teachers that were children enrolling in our schools during the 1980s and prior. When bilingual education was controversial, non-existent or worse, punishable [54]. Did the educational system then not push them into English at all costs regardless of the outcome for their native language? Their early childhood schooling experience fostered English hegemony; and their secondary foreign-language Spanish classes acted upon linguistic purism and elitism [11]. It is because of that mentality and instructional implementation that there still is a teacher shortage today. And until there are large numbers of bilingual programs that embrace both languages and are truly taught through two languages, not just said to be on paper, until then, will this viscous cycle come to an end.

"Despite the well-documented benefits of bilingualism, current educational practices in the United States reflect the deeply held belief that because the United States is an English speaking country, English should be the language of instruction" [27]. At this day and age, this same program debate cannot continue. The need for research has passed; the wondering of which program is best has passed, and the days of settling for subtractive programs that do not have a true bilingual, biliterate, and bicultural focus should be done too. Research has proven the cognitive, social, economic, linguistic, cultural and academic benefits of bilingualism. Research has shown the program that can best help our early childhood emergent bilinguals learn English while also taking advantage of all these benefits. Therefore, when students are not being successful at a dual language campus or district, the solution is not to dismantle the program, but instead question and address its implementation. Similar to other things in life, when dual language programs seem to fail, a solution needs to be found without rejecting the entire approach. Deficiently trained and unsupported teachers, a lack of culturally relevant curriculum, and underfunded 
programs continue to contribute to the lack of success and dehumanization of linguistic and cultural values of language minority groups [9]. The demands of the 1960s for a quality bilingual education that builds upon linguistic and cultural repertoires are still true today [17]. Funding is needed; resources are needed; an intentional focus on professional development is needed; motivation and empowerment of teachers is needed; strong leadership teams that encourage and also believe are needed. More than ever, educators need each other. We must continue to stand together and stand firm in what we know is true and right.

\section{Conclusions and Implications}

In an autoethnography analyzing her journey as a teacher who began to teach during the experimental BEA era, Escamilla [20] recognizes that we are dealing with many of the same challenges we were confronted with half a century ago. They are the same arguments that now have research to show they hold no validity and yet we continue to fight the same battle.

Moving forward, there is no doubt that continued research in bilingual education is warranted. Nonetheless, considering the similarity of the arguments through the decades, there should be a strong effort to shift the focus to creativity and cognitive power that is used to create cutting-edge new methods in the bilingual education field [49]. I propose that we concentrate our efforts for further research in: (1) dual language programs and pedagogy that is supportive of students at the secondary level; (2) dual language pedagogical practices for students with learning difficulties and their success rates; and (3) empowerment of bilingual teachers as they continue to advocate for more than dual language programs, as they also advocate for social justice.

In the area of dismantling the programs that have brewed from the melting-pot ideology, educators have power. When asked for more prove of dual language program benefits, educators need to remember that historically, perpetuating the question may be an underlying monoglossic melting-pot ideology, and instead center the conversation on social justice and cultural and economic equity [36]. Educators must understand and accept their own bilingual identity so that they will continue to guide their advocacy when they encounter political and social barriers of their own and when advocating for their students [16]. In other words, bilingual teachers need liberation. If bilingual teachers are to best address the needs of their students, they need to be aware of the history and how they themselves might have been impacted by it.

As bilingual educators, we need to see the native language as an asset; we need to know our history and the underlying pervasive ideology that perpetuates doubt; we need to engage in reflexive practice and cultivate an understanding and acceptance of our own bilingual identities. We need to advocate for bilingual education, not as a solution to a problem, but as a pathway to strengthen a skill, a language, which our emergent bilinguals are fortunate to be born into and that gives them a leading-edge into a prosperous future.
Since the 1960s, we have repeatedly chanted "Si Se Puede". In fact, this ascending journey is more like a relay where the baton is being passed up through the years for the present to continue from where the past left off, and for that present to pass it to the future once they have become the past. Personally, I hope I can live to see the day when we can chant "Si Se Pudo".

\section{References}

[1] Agirdag, O. (2014). The long-term effects of bilingualism on children of immigration: Student bilingualism and future earnings. International Journal of Bilingual Education and

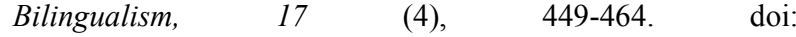
10.1080/13670050.2013.816264.

[2] Archuleta, A. J. \& Perry, A. R. (2016). Family capital: Examining social capital, family commitment, and acculturation among college-enrolled Mexican-American men and women in the Southwestern United States. Journal of Family Social Work, 19 (2), 132-154. doi: $10.1080 / 10522158.2016 .1152523$.

[3] Associated Press. "Bonilla says Reagan bilingual position 'petulant'”. (1981, March 4). Printout.

[4] Associated Press. Reagan blasts programs for bilingual education. (1981, March 3). Printout.

[5] Associated Press. "Bilingual education defended". (1985, October 2). Printout.

[6] Barker, V. \& Giles, H. (2002). Who supports the English-Only movement?: Evidence for misconceptions about Latino group vitality. Journal of Multilingual and Multicultural Development, $23 \quad$ (5), 353-370. doi: $10.1080 / 01434630208666474$.

[7] Bernstein, K. A., Kilinc, S., Deeg, M. T., Marley, S. C., Farrand, K. M. \& Kelley, M. F. (2018). Language ideologies of Arizona preschool teachers implementing dual language teaching for the first time: Pro-multilingual beliefs, practical concerns. International Journal of Bilingual Education and Bilingualism. doi: 10.1080/13670050.2018.1476456.

[8] Blumenfeld, H. K. \& Marian, V. (2013). Parallel language activation and cognitive control during spoken word recognition in bilinguals. Journal of Cognitive Psychology, 25 (5), 547-567. doi: 10.1080/20445911.2013.812093

[9] Borden, R. S. (2014). The English only movement: Revisiting cultural hegemony, Multicultural Perspectives, 16 (4), 229233. doi: $10.1080 / 15210960.2014 .956607$.

[10] Bratz, C. (1981, February 10). Truan offers bilingualeducation bill. American-Statesman Staff.

[11] Briceño, A., Rodríguez-Mojica, C. \& Muñoz-Muñoz, E. (2018). From English learner to Spanish learner: Raciolinguistic beliefs that influence heritage Spanish speaking teacher candidates. Language and Education, 32 (3), 212-226. doi: 10.1080/09500782.2018.1429464.

[12] Bybee, E. R. \& Henderson, K. I. (2014). An overview of U.S. bilingual education: Historical roots, legal battles, and recent trends. All Faculty Publications. 1615. Retrieved from https://scholarsarchive.byu.edu/facpub/1615. 
[13] Carreau, M. \& Hunt, D. (1985, September 27). Criticism of bilingual education is blasted. Houston Post, 18.

[14] Chambers, M. (1986, December 9). Ending bilingual schooling. The New York Times, 65 \& 77. Retrieved from https://www.nytimes.com/1986/12/09/science/educationending-bilingual-schooling.html?searchResultPosition=1 .

[15] Collier, V. P. \& Thomas, W. P. (2017). Validating the power of bilingual schooling: Thirty-two years of large-scale, longitudinal research. Annual Review of Applied Linguistics, 37, 1-15. Retrieved from https://www.thomasandcollier.com/articles.

[16] Collins, B. A., Sánchez, M. T., \& España, C. (2019). Sustaining and developing teachers' dynamic bilingualism in a re-designed bilingual teacher preparation program. International Journal of Bilingual Education and Bilingualism. doi: 10.1080/13670050.2019.1610354.

[17] Degollado, E. D., Bell, R. C. \& Salinas, C. S. (2019). "No había bilingual education:" Stories of negotiation, educación, y sacrificios from south Texas escuelitas. Journal of Latinos and Education. doi: 10.1080/15348431.2019.1604351.

[18] DeMatthews, D. \& Izquierdo, E. (2018). The importance of principals supporting dual language education: A social justice leadership framework. Journal of Latinos and Education, 17 (1), 53-70. doi: 10.1080/15348431.2017.1282365.

[19] De Rossi, D. V. (2012). The English-only movement in the United States. Iperstoria. Retrieved from http://www.iperstoria.it/vecchiosito/httpdocs/?p=547.

[20] Escamilla, K. (2018). Growing up with the Bilingual Education Act: One educator's journey. Bilingual Research Journal, $41 \quad$ (4), 369-387. doi: $10.1080 / 15235882.2018 .1529641$.

[21] Flores, L. (1985, October 4). [Letter] Bilingual Students Sharper. Hispanic Link Weekly Newsletter, Vol. 3 (35).

[22] Fiske, E. B. (1985, September 26). Reagan aide to seek bilingual policy shift. New York Times Service, A6.

[23] Fitzsimmons-Doolan, S., Palmer, D. \& Henderson, K. (2017). Educator language ideologies and a top-down dual language program. International Journal of Bilingual Education and $\begin{array}{llll}\text { Bilingualism, } & 20 & \text { (6), 704-721. doi: }\end{array}$ 10.1080/13670050.2015.1071776.

[24] Foster, W. M., Coraiola, D. M., Suddaby, R., Kroezen, J. \& Chandler, D. (2017). The strategic use of historical narratives: a theoretical framework. Business History, 59 (8), 1176-1200. doi: 10.1080/00076791.2016.1224234.

[25] Franquiz, M. E. \& Jiménez-Castellanos, O. (2018). Coeditor's introduction: Revisiting 50 years of challenges and possibilities. Bilingual Research Journal, 41 (4), 313 - 317. doi: 10.1080/15235882.2018.1545504.

[26] García, O. \& Sung, K. K. (2018). Critically assessing the 1968 bilingual education act at 50 years: Taming tongues and Latinx communities. Bilingual Research Journal, 4 (4), 318 333. doi: 10.1080/15235882.2018.1529642.

[27] Garrity, S., Aquino-Sterling, C. R., Liew, C. V. \& Day, A. (2018). Beliefs about bilingualism, bilingual education, and dual language development of early childhood preservice teachers raised in a Prop 227 environment. International Journal of Bilingual Education and Bilingualism, 21 (2), 179196. doi: 10.1080/13670050.2016.1148113.
[28] Garza-Reyna, G. L. (2019). The academic preparedness of Latino students in dual language and transitional bilingual education programs. Journal of Latinos and Education, 18 (4), 340-348. doi: 10.1080/15348431.2017.1394858.

[29] Garza-Reyna, G. L., Esquierdo, J. J. \& Goswami, J. (2019). A comparative study on the college readiness of bilingual learners in transitional bilingual and dual language programs. NABE Journal of Research and Practice, 9 (3-4), 155-165. doi: 10.1080/26390043.2019.1653046.

[30] Gordon, M. M. (2010). Assimilation in American Life the Role of Race, Religion and National Origins. Oxford University Press.

[31] Hechinger, F. N. (1983, May 31). A humane look at bilingual schooling. The New York Times, 44. Retrieved from https://www.nytimes.com/1983/05/31/science/about-education-ahumane-look-a-bilingual-schooling.html?searchResultPosition=1.

[32] Hensel, B. (1985, September 27). City educators angry with education chief. Houston Post, 12.

[33] Hernandez, J. A. (2004). English-only proponents push legislation. Journal of American Indian Higher Education, 15 (3). Retrieved from https://tribalcollegejournal.org/englishonly-proponents-push-legislation/.

[34] Huddy, L. \& Sears, D. O. (1995). Opposition to bilingual education: Prejudice or the defense of realistic interests? Social Psychology Quarterly, 58, 133-143. doi: $10.2307 / 2787151$.

[35] Kim, Y. Y. (2007). Ideology, identity, and intercultural communication: An analysis of differing academic conceptions of cultural identity. Journal of Intercultural Communication Research, 36 (3), 237-253. doi: 10.1080/17475750701737181.

[36] Macedo, D. \& Bartolomé, L. I. (2014). Multiculturalism permitted in English only. International Multilingual Research Journal, 8 (1), 24 - $37 . \quad$ doi: 10.1080/19313152.2014.852426.

[37] Marzecova, A., Bukowski, M., Correa, A., Boros, M., Lupiáñez, J. \& Wodniecka, Z. (2013). Tracing the bilingual advantage in cognitive control: The role of flexibility in temporal preparation and category switching. Journal of Cognitive Psychology, 25 (5), 586-604. doi: 10.1080/20445911.2013.809348.

[38] Melvin, A. (1985, September 16). The bilingual problem grows. Dallas News.

[39] Morris, D. R. (1985, October 8). Bilingual education: A problem with no easy solution. Houston Post.

[40] Morales, J., Gómez-Ariza, C. J. \& Bajo, M. T. (2013). Dual mechanisms of cognitive control in bilinguals and monolinguals. Journal of Cognitive Psychology, 25 (5), 531546. doi: 10.1080/20445911.2013.807812.

[41] Mujica, B. (1984, February 26) Bilingualism's Goal. The New York Times, 17. Retrieved from https://www.nytimes.com/1984/02/26/opinion/bilingualismsgoal.html?searchResultPosition=1.

[42] Mujica, B. (1990, September 30) Counterpoint: English, Not Spanish. The New York Times, 4. Retrieved from https://www.nytimes.com/1990/09/30/opinion/counterpointenglish-not-spanish.html?searchResultPosition=2 . 
[43] Mujica, B. (2020, April 17). Structured interview. Virtual Zoom.

[44] Murchison, W. (1985, October 3). The bilingual hot potato. Dallas News.

[45] New York Times. (1983, May 14). End the bilingual monopoly. The New York Times, 22. Retrieved from https://www.nytimes.com/1983/05/14/opinion/end-thebilingual-monopoly.html? searchResultPosition=1.

[46] New York Times. (1983, September 13). Si quiere promover English. The New York Times, 22. Retrieved from https://www.nytimes.com/1983/09/13/opinion/si-quierepromover-english.html?searchResultPosition $=1$.

[47] New York Times News Service. (1985 August 26). Pshychologists hear bilingualism backed. Los Angeles.

[48] Nordgren, K. (2016). How to do things with history: Use of history as a link between historical consciousness and historical culture. Theory \& Research in Social Education, 44 (4), 479-504. doi: 10.1080/00933104.2016.1211046.

[49] Olague, R. \& Nzai, V. E. (2013). Bilingual education: In need of a new political strategy. Journal of Latinos and Education, 12 (4), 271-276. doi: 10.1080/15348431.2013.785406.

[50] Perez, F. (1985, October 7). Educators, leaders attack Bennett's proposals. Hispanic Link Weekly Report.

[51] Perez, D. M. C. (2012). The joy of writing my history: Ethnic identity and education through my mother. Action in Teacher

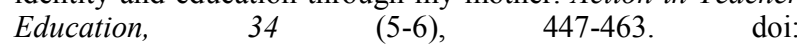
$10.1080 / 01626620.2011 .626752$.

[52] Rebhun, U. (2015). Assimilation in American life: An empirical assessment of Milton Gordon's Multi-dimensional theory. Journal of Contemporary Religion, 30 (3), 473-496. doi: 10.1080/13537903.2015.1081350.

[53] Retz, T. (2017). The structure of historical inquiry. Educational Philosophy and Theory, 49 (6), 606-617. doi 10.1080/00131857.2015.1101365.

[54] Rodriguez, R. (2020, February 21). Bilingual Education. Texas State Historical Association. Retrieved from https://tshaonline.org/handbook/online/articles/jrrht.

[55] Russell, J. W. (1987, March 22). Expand bilingual education. The New York Times, 11

[56] Sanchez, F. (1985, September 27). Bilingual education is defended. Corpus Christi Caller, 16A.

[57] Sanchez, C. (2017, February 23). English Language Learners: How Your State is Doing. National Public Radio. Retrieved from

https://www.npr.org/sections/ed/2017/02/23/512451228/5million-english-language-learners-a-vast-pool-of-talent-at-risk.
[58] Schramm, A. (1985, September 27). Administration claims bilingual education failed. San Antonio Light.

[59] Shannon, W. V. (1985, October 6). Fact is, bilingual education doesn't work. Houston Chronicle.

[60] Stuart, R. (1983, August 21). The new pluralism; In Miami, bilingual means progress. The New York Times. Retrieved from https://www.nytimes.com/1983/08/21/education/thenew-pluralism-in-miami-bilingual-meansprogress.html?searchResultPosition=1.

[61] Sullivan, S. W. (1985, September 30). Bilingual education: School districts should experiment with a variety of different programs. Corpus Christi, Texas, 14A.

[62] Sung, K. K. (2017). "Accentuate the positive; eliminate the negative": Hegemonic interest convergence, racialization of Latino poverty, and the 1968 bilingual education act. Peabody Journal of Education, 92 (3), 302-321. doi: 10.1080/0161956X.2017.1324657.

[63] Thomas-Sunesson, D., Hakuta, K. \& Bialystok, E. (2018). Degree of bilingualism modifies executive control in Hispanic children in the USA. International Journal of Bilingual Education and Bilingualism, 21 (2), 197-206. doi: 10.1080/13670050.2016.1148114.

[64] Morita-Mullaney, T., Renn, J. \& CHIU, M. M. (2020). Contesting math as the universal language: A longitudinal study of dual language bilingual education language allocation. International Multilingual Research Journal. doi: 10.1080/19313152.2020.1753930.

[65] Werner, L. M. (1987, January 16). Reagan bill asks flexibility in funds for bilingual education. The New York Times, 18. Retrieved from https://www.nytimes.com/1987/01/16/us/reagan-bill-asksflexibility-in-funds-for-bilingualeducation.html?searchResultPosition=1.

\section{Biography}

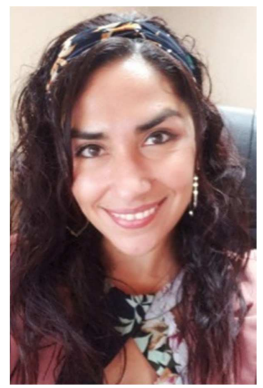

Betty Alicia Cárdenas is currently an Elementary Assistant Principal at Rio Hondo Independent School District in Texas. With a Master's degree in Educational Leadership, Mrs. Cárdenas is currently pursuing her $\mathrm{PhD}$ in bilingual education with the University of TX A\&M Kingsville. Formerly a Bilingual and Special Education Specialist, and bilingual education teacher, her research interests include bilingual education programs, policies, and instructional practices that positively impact student performance. 